\title{
Blasts More than 20 Percent of Peripheral Blood White Cells
}

National Cancer Institute

\section{Source}

National Cancer Institute. Blasts More than 20 Percent of Peripheral Blood White Cells. NCI Thesaurus. Code C150461.

A semi-quantitative microscopic finding indicating that more than 20 percent of the nucleated cells in a peripheral leukocyte sample are immature mononuclear cells. 